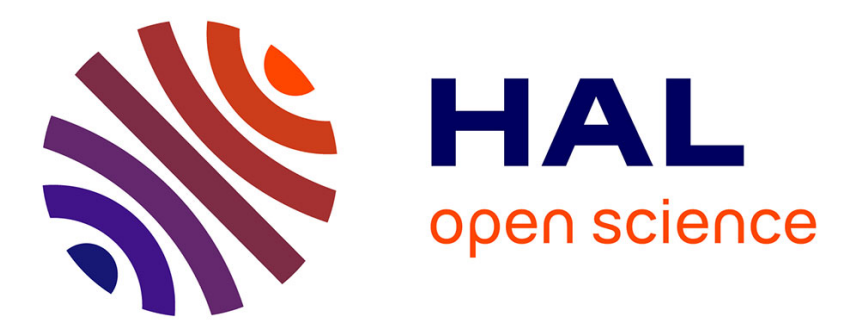

\title{
Horse madness (hippomania) and hippophobia
}

Yiannis G. Papakostas, Michael D. Daras, Ioannis A. Liappas, Manolis

\author{
Markianos
}

\section{To cite this version:}

Yiannis G. Papakostas, Michael D. Daras, Ioannis A. Liappas, Manolis Markianos. Horse madness (hippomania) and hippophobia. History of Psychiatry, 2005, 16 (4), pp.467-471. 10.1177/0957154X05051459. hal-00570821

\section{HAL Id: hal-00570821 \\ https://hal.science/hal-00570821}

Submitted on 1 Mar 2011

HAL is a multi-disciplinary open access archive for the deposit and dissemination of scientific research documents, whether they are published or not. The documents may come from teaching and research institutions in France or abroad, or from public or private research centers.
L'archive ouverte pluridisciplinaire HAL, est destinée au dépôt et à la diffusion de documents scientifiques de niveau recherche, publiés ou non, émanant des établissements d'enseignement et de recherche français ou étrangers, des laboratoires publics ou privés. 


\title{
Horse madness (hippomania) and hippophobia
}

\author{
YIANNIS G. PAPAKOSTAS ${ }^{\star}$ \\ Athens University Medical School \\ MICHAEL D. DARAS \\ Columbia University \\ IOANNIS A. LIAPPAS \\ Athens University Medical School \\ MANOLIS MARKIANOS \\ Athens University Medical School
}

\begin{abstract}
Anthropophagic horses have been described in classical mythology. From a current perspective, two such instances are worth mentioning and describing: Glaucus of Potniae, King of Efyra, and Diomedes, King of Thrace, who were both devoured by their horses. In both cases, the horses' extreme aggression and their subsequent anthropophagic behaviour were attributed to their madness (hippomania) induced by the custom of feeding them with flesh. The current problem of 'mad cow' disease (bovine spongiform encephalopathy) is apparently related to a similar feeding pattern. Aggressive behaviour in horses can be triggered by both biological and psychological factors. In the cases cited here, it is rather unlikely that the former were the cause. On the other hand, the multiple abuses imposed on the horses, coupled with peoples' fantasies and largely unconscious fears (hippophobia), may possibly explain these mythological descriptions of the 'horse-monsters'.
\end{abstract}

Keywords: cow-madness; hippomania; hippophobia; horse-madness

\section{Introduction}

Cases of horses attacking and even devouring humans have been described

* Address for correspondence: Athens University Medical School, Eginition Hospital, 72-74 Vas. Sophias Avenue, 11528, Athens, Greece. Email: yiargeke@hol.gr 
on several occasions in Classical Greek mythology. After insulting the god Dionysus, Lycurgus (King of the Edonians) was driven mad and led to Mount Pangaeum where wild horses pulled his body apart (Apollodorus, 1995). Hippomenes punished his daughter, Leimone, for having a premarital affair by imprisoning her with a horse that grew mad from hunger and ate the young woman (Diodoros, 1993). From a current perspective, two such instances stand out because their horses' anthropophagic behaviour was attributed to feeding the horses with flesh: the cases of Glaucus, King of Corinth, and of Diomedes, King of Thrace. This calls to mind the current problem of 'mad cow' disease (bovine and other animal transmissible spongiform encephalopathies (BSE and TSE, respectively) or prion diseases) which is apparently related to a similar feeding pattern, i.e., mixing meat products in their food (Masood, 1996). It is, therefore, interesting to study these two mythical stories - immortalized by the great Greek tragedy writers Aeschylus (1983) and Euripides (1988) - in conjunction with the current issue of 'mad cow' disease.

\title{
Mythological horse madness (hippomania)
}

\section{Glaucus of Potniae and the crazy mares}

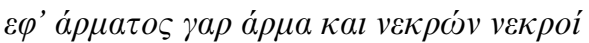

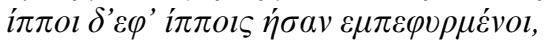

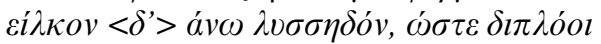

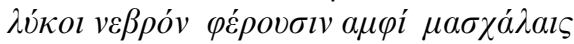

'For chariot on chariot, corpse upon corpse, horse on horse, had been heaped in confusion. In their fury they dragged him aloft, even as two wolves bear off a fawn by its shoulders'

\section{(Aeschylus: Fragments from the lost tragedy 'Glaucus of Potniae')}

Glaucus, son of Sisyphus and Merope, King of Ephyra (which later became Corinth), kept mares at Potniae, a city in Boeotia near Thebes. To make them more eager-spirited than those of other contestants in the chariot races, he fed them on human flesh, a custom that later proved to be fatal. In the middle of a race the mares, in a state of fury, overthrew the chariot, dragged Glaucus on the ground and entangled in the reins for the whole length of the stadium, and ate him alive. The mares' madness was attributed to Glaucus' violation of nature by feeding them with human flesh and by preventing them from mating. This insulted Aphrodite who made the mares eat the poisonous grass hippomanes which brought them to a state of fury. Still another version claims that their madness was caused by their drinking 'magic' water (Kakridis, 1986a). 
Diomedes the Thracian and his fury mares

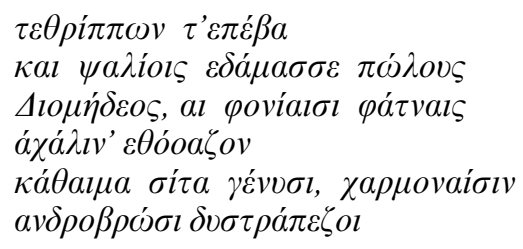

'And on Diomede's [sic] chariot he rode, for he reined them, by his bits overmastered, the stallions four that had ravined at mangers of murder, and stain them with revel of banquets of horror, when gore from men's limbs dripped that their fierce teeth tore'

(Euripides: 'Madness of Hercules')

In the eighth labour, Hercules was ordered to capture the four savage horses of the Thracian King Diomedes - named Podagros (the fast), Lampon (the shining), Xanthos (the blond) and Deinos (the terrible) - and bring them to Mycenae. Diomedes, son of the god Ares and the nymph Cyrene, and King of the Bistones (a war-like people of Thrace), kept the mares tethered with iron chains to bronze mangers and fed them on the flesh of unsuspecting guests. Hercules captured the mares and drove them down to the sea under the charge of his minion, Abderus. According to the myth the mares devoured Diomedes as well as Abderus. Again the frenzy of the mares was attributed to the violation of eating habits by consuming human flesh or by drinking water from the river Kossiniti, which used to aggravate the animals (Kakridis, 1986b)

\section{Discussion}

In both mythical cases the fury of the mares (hippomania) and the subsequent anthropophagic behaviour was attributed to the aberrations in the horses' eating habits, be it the consumption of animal and/or human flesh, the eating of the herb hippomanes or the drinking of 'magic' water. It is tempting to draw analogies with the current issue of 'mad cow' disease. Horses can occasionally 'go crazy' (Beaver, 1986), like cows suffering from TSE that can occasionally progress to frenzy, hence the name 'mad cows' (Haywood, 1997). In addition, like the mythical horses' madness and anthropophagi, 'cow madness' is transmissible and thus threatening to humans. Finally, cow madness has also been attributed to similar dietary violations, flesh feeding, like the mythological horse madness.

Aggression in horses may result from many causes. Failure to meet the basic needs inherited in their nature may result in equine aggression in zoos (Boyd, 1986). Specifically, aggression can be induced by diverse stimuli such as fear and pain, intermale struggle or struggle for dominance, learned or 
play aggression and protective-maternal or sex-related aggression (Beaver, 1986). The unnatural situations in which these scared and fearful horses had lived can easily explain their aggressive behaviour. Horse aggression can also be caused by medical problems, such as chronic pain due to arthritis, navicular disease, bursitis, hypertestosteronism, genetic factors, brain dysfunction and self-mutilation (Beaver, 1986) and viral encephalopathies including rabies (Kaaden, Eichhorn and Essbauer, 2002; Roos, 1999).

Biological explanations are highly unlikely. Horses can metabolize proteins of animal origins, a capacity that seems interesting from an evolutionary perspective. Indeed, feeding horses with flesh is not uncommon, for example, fish is given to racing horses in California, blood from pigs to horses in Tibet, and chickens to horses in Valouchistan (Devereux, 1975). Viral encephalitis, however, including rabies, cannot be contacted by eating the meat of an infected animal or by the devouring of healthy human flesh, as we can assume their victims were. TSE can occur in man as well as several animals (Prusiner, 1993), but, so far, has not been reported in horses (Lanning, 2002). Besides, these mythical horses displayed an extremely aggressive behaviour in targeting humans, which is not part of the clinical picture of TSE disease in animals - they usually present with wasting, ataxia and inability to walk or eat. Apparently, the absence of TSE in horses can explain the increase of horse-meat consumption in Europe when the fear of 'mad cow' disease erupted.

Biological explanations of horse-madness (or 'hippomania') and the anthropophagic behaviour, which surpassed the usual aggression and inspired awe, seem rather weak, so psychological explanations may be more suitable. Fear of horses ('hippophobia') is a well-known condition, thanks to Freud's famous case of 'little Hans'. The origin of this fear is psychoanalytically explained and attributed to the Oedipus complex, with the physical and symbolic feature of the horse reminiscent of a beastly father threatening the maleness of his child. The painful idea of hating the beloved father is displaced upon a horse (Nunberg, 1955). Indeed the picture of an agitated horse warning, threatening or attacking an intruder by kicking, striking, rearing, pawing and showing its large incisors (Beaver, 1986) may appear quite frightening to humans. Virgil offered his witness that a full-blown aggression displayed by mares surpasses that of many other animals such as lynxes, wolves, dogs and stags, and he cites Glaucus' tragic death to support his argument (Virgil, 1999). Similarly, panicky horses flying in fury can become dangerous to themselves and people (Beaver, 1986). This was the case with the ancient heroes Hippolytus and Oenomaus, who were killed by their horses running in panic. Thus, horse-inspired fear may steer human imagination even to include anthropophagic behaviour. The fear of horses may be exaggerated through stretched imagination leading to the creation of the 'horse-monsters' such as the Centaurs, the Trojan Horse and the Indian Monokerata Hippoi. Nevertheless, the possibility that the exaggerated fear of 
horses (hippophobia) was initiated or reinforced by true instances of horses' anthropophagic behaviour some time during evolutionary history is still open to inquiry.

\section{References}

Aeschylus, 'Fragments', translated by H. W. Smyth and H. Lloyd-Jones. In G. P. Goold (ed.) (1983) Aeschylus. Vol II: Agamemnon, Libation-Bearers, Eumenides, Fragments (Cambridge, MA: Harvard University Press, The Loeb Classical Library), fragments 22-23 (pp. 391-3).

Apollodorus, 'The Library', translated by J. G. Frazer. In G. P. Goold (ed.) (1995) Apollodorus: The Library, Vol. I, Book I, II, III (Cambridge, MA: Harvard University Press, The Loeb Classical Library), Book III, V, 1 (pp. 324-9).

Beaver, B. V. (1986) Aggressive behavior problem. Veterinary Clinics of North America: Equine Practice, 2, 635-44.

Boyd, L. (1986) Behavior problems of equids in zoos. Veterinary Clinics of North America: Equine Practice, 2, 653-64.

Devereux, G. (1975) Les chevaux anthropophages dans les mythes Grecs. Revue des Études Grecques, 88, 203-5.

Diodorus Siculus, 'Fragments', translated by C. H. Oldfather. In G. P. Goold (ed.) (1993) Diodorus Siculus, The Library of History, Vol. III, Books IV.59-VIII (Cambridge, MA: Harvard University Press, The Loeb Classical Library), Fragments of Book VIII, 22, 1 (pp. 414-15).

Euripides, 'Madness of Hercules', translated by A. S. Way. In G. P. Goold (ed.) (1988) Euripides, III: Bacchanals, Madness of Hercules, Children of Hercules, Phoenician Maidens, Suppliants (Cambridge, MA: University Press, The Loeb Classical Library), 380-6 (pp. 156-7).

Haywood, A. M. (1997) Transmissible spongiform encephalopathies. New England fournal of Medicine, 337, 1821-8.

Kaaden, O.-R., Eichhorn, W. and Essbauer, S. (2002) Recent developments in the epidemiology of virus diseases. Fournal of Veterinary Medicine, Series B, 49, 3-6.

Kakridis, I. (1986a) Corynthos (superviser). In Ekdotiki Athinon (ed.), Greek Mythology, Vol. III (Athens: Ekdotiki Athinon), 251.

Kakridis, I. (1986b) Dimoides' horses (superviser). In Ekdotiki Athinon (ed.), Greek Mythology, Vol. III (Athens: Ekdotiki Athinon), 48-50.

Lanning, N. M. (2002) Human and Animal Transmissible Spongiform Encephalopathies including Bovine Spongiform Encephalopathy (WSDA Washington State, Department of Agriculture, May 2002, WA 98504-2560), 1-8.

Masood, E. (1996) 'Mad cow' scare threatens political link between food and agriculture. Nature, 380, 273-4.

Nunberg, H. (1955) Principles of Psychoanalysis: Their Application to the Neuroses (New York: International University Press), 220.

Prusiner, S. B. (1993) Genetic and infectious prion diseases. Archives of Neurology, 50, 1129-53.

Roos, K. L. (1999) Encephalitis. Neurologic Clinics, 17, 813-33.

Virgil, 'Georgics', translated by H. R. Fairclough, revised by G. P. Goold. In J. Henderson (ed.) (1999) Virgil: Vol. I, Eclogues, Georgics, Aeneid 1-6 (Cambridge, MA: Harvard University Press, The Loeb Classical Library), Book III, 264-268 (pp. 194-5). 